\title{
Stereoselective Recognition of Tripeptides Guided by Encoded Library Screening: Construction of Chiral Macrocyclic Tetraamide Ruthenium Receptor for Peptide Sensing
}

\author{
Kuei-Hua Chang, ${ }^{\dagger}$ Jen-Hai Liao,${ }^{\dagger}$ Chao-Tsen Chen, ${ }^{*}{ }^{\dagger}$ Barun K. Mehta,${ }^{\dagger}$ Pi-Tai Chou, ${ }^{*}$ and \\ Jim-Min Fang*,, ; \\ Department of Chemistry, National Taiwan University, Taipei 106, Taiwan, and \\ Genomic Research Center, Academia Sinica, Taipei 115, Taiwan \\ jmfang@ntu.edu.tw
}

Received September 15, 2004

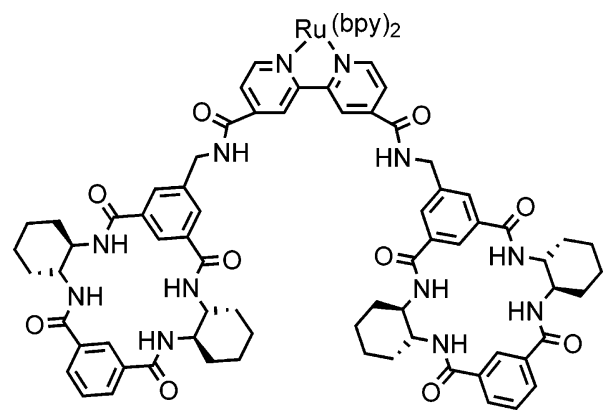

Molecule sensor $\mathbf{1}$ is devised by incorporating the reporting unit of ruthenium(II) complex and two recognition motifs of chiral cyclotetraamides on the sidearms. The target binding tripeptides for sensor 1 were readily identified by using an encoded library screening method. This solid-phase screening indicated a preferable binding of molecule 1 with D-alanine over the L-isomer. The optical and NMR studies for the binding events of $\mathbf{1}$ with tripeptides Ac-Ala-Gly-Ala- $\mathrm{NHC}_{12} \mathrm{H}_{25}$ in the solution phase showed a consistent trend for the stereoselective recognition of the DD-isomer over the LD-, DL-, and LL-isomers.

\section{Introduction}

Fundamental studies of peptide recognition provide a way to investigate the more complicated protein interactions, which are often addressed in chemical biology and drug discovery research. The main binding forces between a peptide and its host receptor include hydrogen bonding, electrostatic, and hydrophobic interactions. ${ }^{1}$ For example, vancomycin is a potent antibacterial agent, which displays quadruple hydrogen bindings with the D-Ala-D-Ala fragment that is essential for formation of bacterial cell wall. ${ }^{2}$ The new strain of bacteria by mutation of the D-Ala-D-Ala dipeptide into D-Ala-D-lactate can resist the attack of vancomycin, presumably due to elimination of a crucial hydrogen bonding and the increase of repulsive electronic interactions between the lactate portion and vancomycin. ${ }^{2}$

$\dagger$ National Taiwan University.

¥ Academia Sinica.

(1) Stites, W. E. Chem. Rev. 1997, 97, 1233.

(2) Healy, V. L.; Lessard, I. A.; Roper, D. I.; Knox, J. R.; Walsh, C. T. Chem. Biol. 2000, 7, R109.
An efficient peptide receptor must exhibit a spacious recognition site in order to accommodate the relatively large guest molecule. For this purpose, acyclic and macrocyclic structures are often applied as the recognition motifs, to which crown ethers can be incorporated to enhance the interaction with the terminal ammonium group of the peptide. ${ }^{3}$ Acyclic peptide receptors are generally constructed by implanting two peptide or multiple-amide chains on a structurally defined backbone, such as steroid, ${ }^{4,5}$ calixarene, ${ }^{6,7}$ diketopiperazine, ${ }^{8}$ and dibenzofuran. ${ }^{9}$ Conversely, a macrocyclic tetraamide receptor has been prepared by using five building blocks

(3) (a) Tsubaki, K.; Kusumoto, T.; Hayashi, N.; Nuruzzaman, M.; Fuji, K. Org. Lett. 2002, 4, 2313. (b) Tsubaki, K.; Nuruzzaman, M.; Kusumoto, T.; Hayashi, N.; Wang, B.-G.; Fuji, K. Org. Lett. 2001, 3, 4071 .

(4) (a) Cheng, Y.; Suenaga, T.; Still, W. C. J. Am. Chem. Soc. 1996, 118, 1813. (b) Boyce, R.; Li, G.; Nestler, H. P.; Suenaga, T.; Still, W. C. J. Am. Chem. Soc. 1994, 116, 7955 .

(5) Muynck, H. D.; Madder, A.; Farcy, N.; Clercq, P. J. D.; PérezPayán, M. N.; Öhberg, L. M.; Davis, N. P. Angew. Chem., Int. Ed. 2000 $39,145$.

(6) van Wageningen, A. M. A.; Liskamp, R. M. J. Tetrahedron Lett. 1999, $40,9347$.

10.1021/jo048368s CCC: $\$ 30.25$ (C) 2005 American Chemical Society Published on Web 02/10/2005 


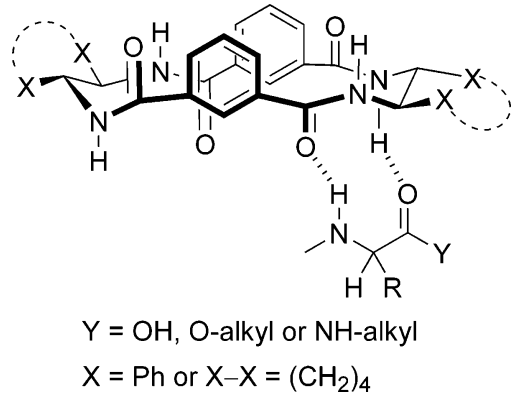

FIGURE 1. $\mathrm{A}_{2} \mathrm{~B}_{2}$ motif formed by two units of isophthalic acid (A) and two units of vicinal diamine $(\mathbf{B})$ in recognition of $\alpha$-amino acid derivatives via double hydrogen bondings.

consisting of 2,6-diaminopyridine, phenylalanine, succinic acid, (4-aminomethyl)phenol, and (4'-bromomethylbiphenyl)acetic acid. ${ }^{10}$ This receptor displays a selective binding to dipeptide $N$-Cbz-( $\beta$-Ala)-Ala. A similar macrocyclic hexaamide receptor is derived from a core structure of 1,3,5-trimercaptobenzene to form a confined deep-basket shape that well accommodates the guest molecule of tripeptide cPr-Ala-Pro-Ala- $\mathrm{NHC}_{12} \mathrm{H}_{25} .{ }^{11} \mathrm{~A}$ podant ionophore $^{12}$ having a three-dimensional framework also shows a sequence-selective recognition of L-Arg-L-Phe-DAsp. Cyclodextrins ${ }^{13}$ and Kemp's acid amide derivatives ${ }^{14}$ are also suitable motifs for peptide recognition. The receptor molecules constructed by incorporation of such motifs exhibit high affinity toward linear and cyclic peptides. A multiloop receptor has been built by extension of four hydrophilic cyclic peptide loops, Gly-Asp-Gly-Asp, on a hydrophobic calix[4]arene core. ${ }^{7}$ This molecular receptor thus provides multiple electrostatic and hydrogen bonding interactions to bind with the surface peptide of cytochrome $c$ that contains abundant lysine residues. ${ }^{7}$

In view of sensing peptides in an enantioselective fashion, of special interest are the molecular receptors with chiral recognition sites, e.g., the $\mathrm{A}_{2} \mathrm{~B}_{2}$ motif of an octadecacyclotetramide structure (Figure 1 ). The $\mathrm{A}_{2} \mathrm{~B}_{2}$ motif is readily constructed by two units of isophthalic acid and two units of $(1 R, 2 R)$-1,2-diphenylethanediamine ${ }^{15}$ [or $(1 R, 2 R)$-1,2-cyclohexanediamine], ${ }^{16}$ in which

(7) (a) Peczuh, M. W.; Hamilton, A. D. Chem. Rev. 2000, 100, 2479. (b) Hamuro, Y.; Calama, M. C.; Park, H. S.; Hamilton, A. D. Angew. Chem., Int. Ed. Engl. 1997, 36, 2680.

(8) (a) Wennemers, H.; Conza, M.; Nold, M.; Krattiger, P. Chem. Eur. J. 2001, 7, 3342. (b) Conza, M.; Wennermers, H. J. Org. Chem. 2002, 67, 2696.

(9) LaBrenz, S. R.; Kelly, J. W. J. Am. Chem. Soc. 1995, 117, 1655. (10) Dowden, J.; Edwards, P. D.; Flack, S. S.; Kilburn, J. D. Chem. Eur. J. 1999, 5, 79.

(11) (a) Borchardt, A.; Still, W. C. J. Am. Chem. Soc. 1994, 116, 373. (b) Borchardt, A.; Still, W. C. J. Am. Chem. Soc. 1994, 116, 7467.

(12) Burger, M. T.; Still, W. C. J. Org. Chem. 1997, 62, 4785.

(13) (a) Breslow, R.; Yang, Z.-W.; Ching, R.; Trojandt, G.; Odobel, F. J. Am. Chem. Soc. 1998, 120, 3536. (b) Breslow, R.; Zhang, B. J. Am. Chem. Soc. 1992, 114, 5882. (c) Breslow, R.; Greenspoon, N.; Guo, T.; Zarzycki, R. J. Am. Chem. Soc. 1989, 111, 8296. (d) Zhang, B.; Breslow, R. J. Am. Chem. Soc. 1993, 115, 9353. (e) Maletic, M.; Wennemers, H.; McDonald, D. Q.; Breslow, R.; Still, W. C. Angew. Chem., Int. Ed. Engl. 1996, 35, 1490.

(14) Jeong, K.-S.; Muehldorf, A. V.; Rebek, J., Jr. J. Am. Chem. Soc. $1990,112,6144$.

(15) Gasparrini, F.; Misiti, D.; Pierini, M.; Villani, C. Org. Lett. 2002, 4, 3993.

(16) (a) Wennemers, H.; Yoon, S. S.; Still, W. C. J. Org. Chem. 1995 60, 1108. (b) Still, W. C. Acc. Chem. Res. 1996, 29, 155. (b) Hu, K. Bradshaw, J. S.; Dalley, N. K.; Krakowiak, K. E.; Wu, N.; Lee, M. L. J. Heterocycl. Chem. 1999, 36, 381. (d) Gasparrini, F.; Misiti, D.; Still, W. C.; Villani, C.; Wennemers, H. J. Org. Chem. 1997, 62, 8221.
$\mathrm{NH}$ of the amido group and $\mathrm{C}=\mathrm{O}$ of the vicinal amido group form an ideal hydrogen donor/acceptor pair suitable for bonding with $\alpha$-amino acid derivatives. ${ }^{15,16}$ This chiral receptor is expected to exert different complexation strengths with respect to D- and L-amino acid derivatives. Previous HPLC studies ${ }^{15,16 \mathrm{~d}}$ have revealed that chiral columns using $\mathrm{A}_{2} \mathrm{~B}_{2}$ derivatives as a stationary phase are applicable to the separation of derivatized isomers of $\alpha$-amino acids and tripeptides. In this regard, the cage compound with an $\mathrm{A}_{4} \mathrm{~B}_{6}$ motif also serves as a receptor for dipeptide and tripeptide derivatives. ${ }^{11,} 17$

As for the signal transduction, the molecular receptors of $\mathrm{A}_{2} \mathrm{~B}_{2}$ and $\mathrm{A}_{4} \mathrm{~B}_{4}$ scaffolds are elaborated to detect peptide derivatives by attaching suitable fluorophore/quencher pairs, e.g., dansyl and dabcyl, via the fluorescence resonance energy transfer (FRET) mechanism. ${ }^{18}$ In the absence of guest molecule, the free receptor shows rather weak fluorescence due to the efficient FRET, followed by the dominant nonradiative deactivation pathways. Upon complexation with the target peptide, an enhanced fluorescence is observed as the fluorophore and quencher are pushed apart.

On the basis of the protocol of two-armed receptors devised by Still's group, ${ }^{11,16,17}$ we demonstrate herein a novel molecule sensor $\mathbf{1}$ that is used to detect tripeptides with a high sequence- and stereoselectivity. Compound $\mathbf{1}$ is designed to incorporate two $\mathrm{A}_{2} \mathrm{~B}_{2}$ motifs as the recognition units ${ }^{16 \mathrm{a}, \mathrm{d}}$ and a tris(bipyridine) ruthenium(II) complex as the signal transduction unit (Figure 2). The two macrocyclic $\mathrm{A}_{2} \mathrm{~B}_{2}$ units are linked to a bipyridine moiety via two amide bonds. Thus, the multiple-amide unit provides a desirable semirigid structure and sufficient hydrogen bonding sites for peptide recognition. The appropriate disposition of two $\mathrm{A}_{2} \mathrm{~B}_{2}$ motifs in molecule 1 may also enhance the binding with the target peptides in a cooperative manner. ${ }^{16}$ The $\mathrm{Ru}(\mathrm{II})$ center is sensitive to the binding event so that the changes of luminescence properties and redox potential can be readily monitored and correlated to the binding strength. ${ }^{19}$

\section{Results and Discussion}

Synthesis. Molecular sensor 1 was constructed by five building blocks: isophthalic acid bis-chloride $(\mathbf{2}),(R, R)$ cyclohexane-1,2-diamine (3), 5-(azidomethyl)isophthalic acid (4), 2,2'-bipyridine-4,4'-dicarboxylic acid (5), and cis(bpy) ${ }_{2} \mathrm{RuCl}_{2}(\mathbf{6})$. When diamine $\mathbf{3}$ was treated with $\mathrm{Boc}_{2} \mathrm{O}$, a mixture of mono-Boc and di-Boc derivatives were obtained. To avoid this complication, an indirect method was applied to prepare the mono-Boc derivative $\mathbf{7}$ (Scheme 1) ${ }^{20}$ Thus, diamine 3 was first converted to the $N, N^{\prime}$-bis$\mathrm{Cbz}$ derivative, which was then reacted selectively with

(17) (a) Yoon, S. S.; Still, W. C. J. Am. Chem. Soc. 1993, 115, 823. (b) Yoon, S. S.; Still, W. C. Tetrahedron 1995, 51, 567.

(18) (a) Chen, C.-T.; Wagner, H.; Still, W. C. Science 1998, 279, 851 (b) Rothman, J. H.; Still, W. C. Bioorg. Med. Chem. Lett. 1999, 9, 509 (19) Sauvage, J.-P.; Collin, J.-P.; Chambron, J.-C.; Guillerez, S. Coudret, C.; Baltani, V.; Barigelletti, F.; De Cola, L.; Famigni, L. Chem. Rev. 1994, 94, 993. (a) Szemes, F.; Hesek, D.; Chen, Z.; Dent, S. W.; Drew, M. G. B.; Goulden, A. J.; Graydon, A. R.; Grieve, A.; Mortimer R. J.; Wear, T.; Weightman, J. S.; Beer, P. D. Inorg. Chem. 1996, 35, 5868. (b) Prasanna de Silva, A.; Nimal Guaratne, H. Q.; Gunnlaugsson, T.; Huxley, A. J. M.; McCoy, C. P.; Rademacher, J. T.; Rice, T. E. Chem. Rev. 1997, 97, 1515. (c) Keefe, M. H.; Benkstein, K. D.; Hupp, J. T. Coord. Chem. Rev. 2000, 205, 201.

(20) Kim, Y. Y.; Lee, S. J.; Ahn, K. H. J. Org. Chem. 2000, 65, 7807. 

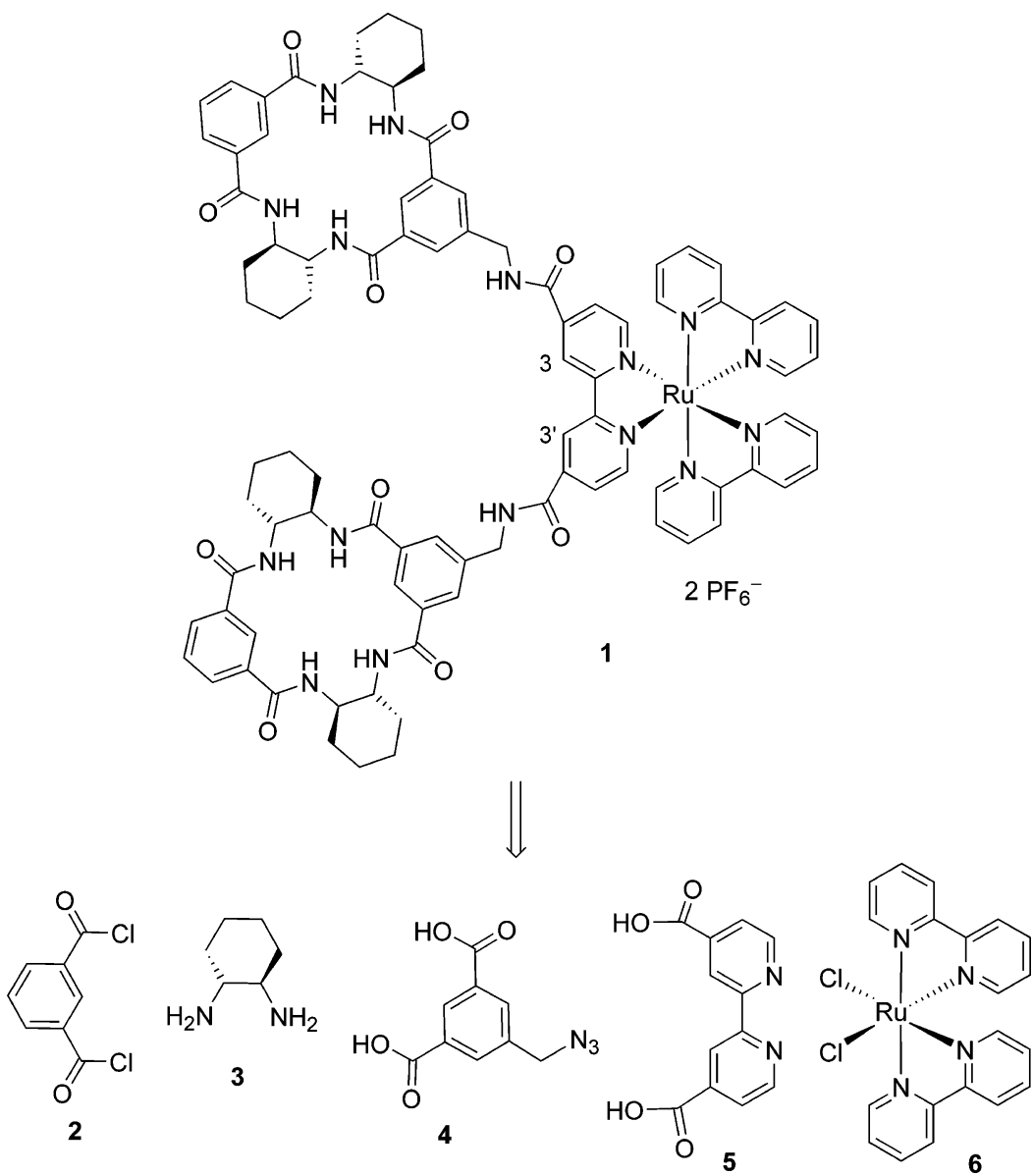

FIGURE 2. Construction of molecular sensor 1 by five building blocks: isophthalic acid bis-chloride (2, two units), (1R,2R)cyclohexane-1,2-diamine (3, four units), 5-(azidomethyl)isophthalic acid (4, two units), 2,2'-bipyridine-4,4'-dicarboxylic acid (5, one unit), and cis-(bpy) ${ }_{2} \mathrm{RuCl}_{2}$ (one unit).

\section{SCHEME 1. Synthesis of Molecular Sensor $\mathbf{1}^{a}$}
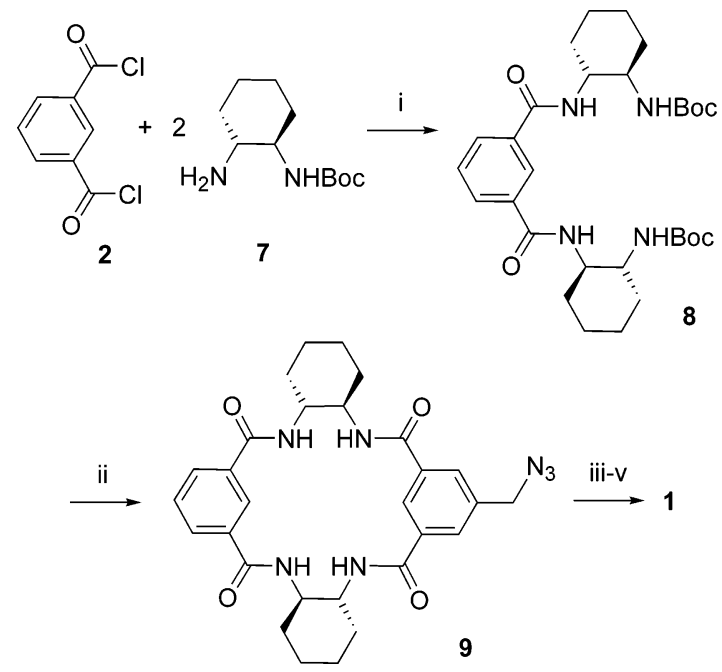

${ }^{a}$ Reagents and conditions: (i) $i$ - $\mathrm{Pr}_{2} \mathrm{NEt}, \mathrm{CH}_{2} \mathrm{Cl}_{2}, 25{ }^{\circ} \mathrm{C}, 3 \mathrm{~h}, 95 \%$; (ii) TFA, $\mathrm{CH}_{2} \mathrm{Cl}_{2}, 25{ }^{\circ} \mathrm{C}, 1.5 \mathrm{~h}$, then $\operatorname{diC}_{6} \mathrm{~F}_{5}$-ester of $4, i$ - $\mathrm{Pr}_{2} \mathrm{EtN}$, THF, $25^{\circ} \mathrm{C}, 12 \mathrm{~h}, 99 \%$; (iii) $\mathrm{Ph}_{3} \mathrm{P}$, THF, reflux, $2 \mathrm{~h}, \mathrm{H}_{2} \mathrm{O}$, THF, reflux, $14 \mathrm{~h}, 87 \%$, or $\mathrm{H}_{2}, 10 \% \mathrm{Pd} / \mathrm{C}, \mathrm{MeOH}, 25{ }^{\circ} \mathrm{C}, 8 \mathrm{~h}, 99 \%$; (iv) diacid 5, EDC, HOBt, DMF, rt, 49 h, 87\%; (v) 6 (hydrate), EtOH, $\mathrm{H}_{2} \mathrm{O}$, reflux, $6 \mathrm{~h}, \mathrm{NH}_{4} \mathrm{PF}_{6}, 83 \%$.

$\mathrm{Boc}_{2} \mathrm{O}$ to give exclusively the $N$-Boc- $N, N^{\prime}$-Cbz derivative. Attachment of the second Boc group was prohibited presumably due to the sterically demanding environment. After the $\mathrm{Cbz}$ groups were removed by catalytic hydrogenation, the mono-Boc derivative $\mathbf{7}$ was obtained in $67 \%$ overall yield. The coupling reaction of $\mathbf{7}$ ( 2 equiv) with isophthalic acid bis-chloride (2) occurred smoothly in the presence of Hünig base to give diamide $8 .{ }^{16 \mathrm{~b}}$ After removal of the Boc groups by $\mathrm{CF}_{3} \mathrm{COOH}$, the resulting amine (as the TFA salt) was treated with the pentafluorophenyl diester of 5-(azidomethyl)isophthalic acid in the presence of Hünig base to give a cyclotetraamide $\mathbf{9}$. The azido group of $\mathbf{9}$ was reduced by catalytic hydrogenation or by using $\mathrm{Ph}_{3} \mathrm{P} / \mathrm{H}_{2} \mathrm{O}$ (Staudinger reaction); and the amine product (2 equiv) was then reacted with $2,2^{\prime}$ bipyridine-4,4'-dicarboxylic acid (5) using EDC and HOBt as the coupling reagents. The subsequent reaction with cis- $\mathrm{Ru}(\mathrm{bpy})_{2} \mathrm{Cl}_{2}$, followed by exchange of $\mathrm{Cl}^{-}$with $\mathrm{PF}_{6}{ }^{-}$ counterions, thus culminated in the synthesis of sensor 1 with a Ru reporter and double $\mathrm{A}_{2} \mathrm{~B}_{2}$ recognition motifs. Because one of bipyridyl ligands contains the chiral $\mathrm{A}_{2} \mathrm{~B}_{2}$ substituents, the $\mathrm{Ru}(\mathrm{II})$ compound 1 likely exists in two diastereomeric forms with $\Delta$ - or $\Lambda$-configurations at the ruthenium center. This speculation is supported by the NMR study (vide infra).

The $\mathrm{Ru}$ (II) compound $\mathbf{1}$ (as the $\mathrm{PF}_{6}{ }^{-}$salt) appeared as orange red solids. Its $\mathrm{CH}_{2} \mathrm{Cl}_{2}$ solution showed the characteristic absorption bands at $\lambda_{\max }=289 \mathrm{~nm}(\epsilon=73200$ $\mathrm{M}^{-1} \mathrm{~cm}^{-1}$ ) for the bipyridyl ligand and at $\lambda_{\max }=457 \mathrm{~nm}$ $\left(\epsilon=15100 \mathrm{M}^{-1} \mathrm{~cm}^{-1}\right)$ attributable to the metal to ligand 

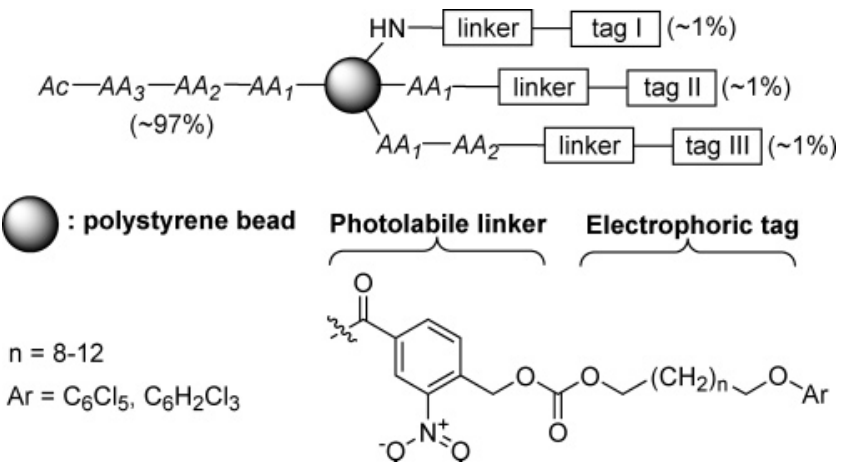

FIGURE 3. Bead-bound tripeptide library with electrophoric tags. Tripeptide $\mathrm{AA}_{1}-\mathrm{AA}_{2}-\mathrm{AA}_{3}$ represents any combination of 15 amino acids: Gly, L-Ala, D-Ala, L-Val, D-Val, L-Ser, D-Ser, L-Pro, D-Pro, L-Asn, D-Asn, L-Gln, D-Gln, L-Lys, and D-Lys.

charge transfer (MLCT) ${ }^{19}$ In more polar media [e.g., a mixed solution of $\mathrm{MeOH} / \mathrm{CHCl}_{3}$ (1:9)], the absorption maxima shifted to longer wavelengths, $299 \mathrm{~nm}(\epsilon=$ $\left.71100 \mathrm{M}^{-1} \mathrm{~cm}^{-1}\right)$ and $465 \mathrm{~nm}\left(\epsilon=15300 \mathrm{M}^{-1} \mathrm{~cm}^{-1}\right)$. Upon excitation at $457 \mathrm{~nm}$, compound $\mathbf{1}\left(2 \times 10^{-6} \mathrm{M}\right)$ exhibited an emission band with peak wavelengths at $595 \mathrm{~nm}(\Phi$ $\sim 0.054)$ and $630 \mathrm{~nm}$ in $\mathrm{CH}_{2} \mathrm{Cl}_{2}$ and $\mathrm{MeOH} / \mathrm{CHCl}_{3}$ (1:9), respectively. The relatively long lifetime of $1.2 \mu \mathrm{s}$ measured in aerated $\mathrm{CH}_{2} \mathrm{Cl}_{2}$ leads us to unambiguously assign the 595-nm emission (or $630 \mathrm{~nm}$ in $\mathrm{MeOH} / \mathrm{CHCl}_{3}$ ) to a phosphorescence manifold. In degassed $\mathrm{CH}_{2} \mathrm{Cl}_{2}$ the lifetime increases to $1.7 \mu \mathrm{s}$. Taking $\mathrm{O}_{2}$ concentration of $2.6 \times 10^{-3} \mathrm{M}$ in aerated $\mathrm{CH}_{2} \mathrm{Cl}_{2},{ }^{21}$ an $\mathrm{O}_{2}$ quenching rate constant of $\sim 9.0 \times 10^{7} \mathrm{M}^{-1} \mathrm{~s}^{-1}$ was thus deduced, which is $\sim 20$ times smaller than $1 / 9$ of the diffusion controlled rate of $1.8 \times 10^{10} \mathrm{M}^{-1} \mathrm{~s}^{-1}$ calculated in $\mathrm{CH}_{2} \mathrm{Cl}_{2} .{ }^{22}$ Note that the $\mathrm{O}_{2}$-triplet quenching rate is generally derived from the theory of electron-exchange type of energy transfer, in which the overall spin must be conserved upon forming a collisional complex. Accordingly, the possibility of each collision generating ${ }^{1} \mathrm{O}_{2}$ is statistically $1 / 9$. The relatively small $\mathrm{O}_{2}$ quenching constant of $9.0 \times$ $10^{7} \mathrm{M}^{-1} \mathrm{~s}^{-1}$ in 1 clearly indicates that the ${ }^{3} \mathrm{MLCT}$ emission is less effectively quenched by $\mathrm{O}_{2}$ due to the introduction of two chiral cyclotetraamide motifs on the sidearms.

Screening of Tripeptide Library. To find the peptides best fitted to molecule $\mathbf{1}$, we screened a $15 \times 15 \times$ 15 tripeptide library (3375 different combinations) that has been established by Still and co-workers using encoded split combinatorial chemistry (Figure 3).11,16a,23 The tripeptide-bound polystyrene beads incorporate a photocleavable linker (o-nitrobenzyl carbonate) and varied electrophoric tags (chlorinated phenoxyalkanes) for encoding specific sequences of tripeptides.

A typical screening procedure is described as follows. The combinatorial tripeptide beads $(1 \mathrm{mg}$, containing about 4 copies of each tripeptide component) were suspended in $\mathrm{CHCl}_{3}(0.5 \mathrm{~mL})$. A solution of sensor 1 (40 $\left.\mu \mathrm{L}, 1 \times 10^{-3} \mathrm{M}\right)$ in $\mathrm{MeOH} / \mathrm{CHCl}_{3}$ (1:9) was added, and

(21) Murov, S. L.; Carmichael, I.; Hug, G. L. Handbook of Photochemistry, 2nd ed.; Marcel Dekker: New York, 1993.

(22) Birks, J. B. Photophysics of Aromatic Molecules; Wiley: New York, 1970, p 313.

(23) Ohlmeyer, M. H. J.; Swanson, R. N.; Dillard, L. W.; Reader, J. C.; Asouline, G.; Kobayashi, R.; Wigler, M.; Still, W. C. Proc. Natl. Acad. Sci. U.S.A. 1993, 90, 10922.

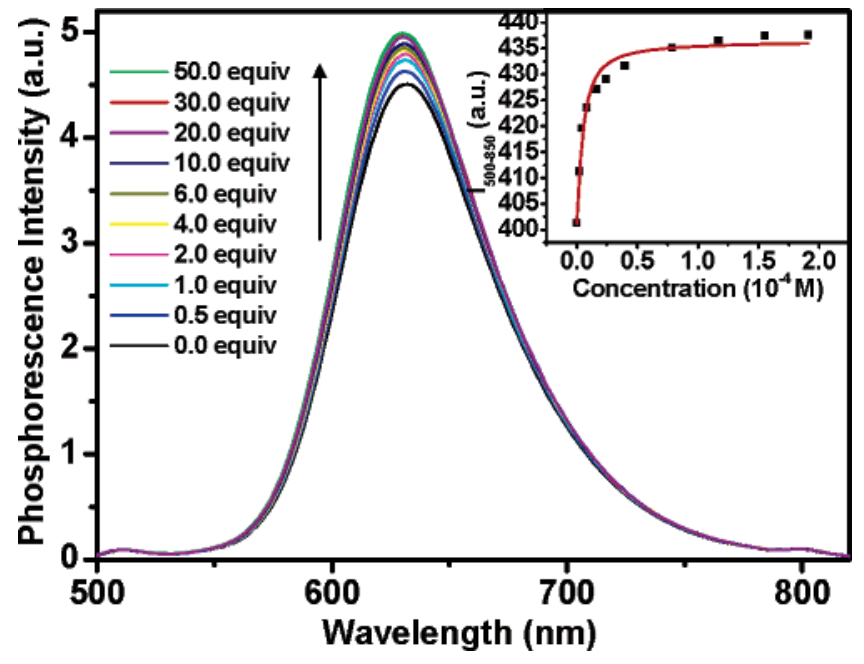

FIGURE 4. Phosphorescence titration spectra of $\mathbf{1}\left(4.0 \times 10^{-6}\right.$ M) by addition of various amounts of the tripeptide derivative 10-DD [as a $4.0 \times 10^{-3} \mathrm{M}$ solution in $\mathrm{MeOH} / \mathrm{CHCl}_{3}$ (1:9)] at $293 \mathrm{~K}, \lambda_{\mathrm{ex}}=466 \mathrm{~nm}$. Inset: A curve fitting of the data using the nonlinear least-squares method. $K_{\mathrm{a}}$ is derived to be $2.9 \times$ $10^{5} \mathrm{M}^{-1}$.

the mixture was agitated for $40 \mathrm{~h}$ to ensure equilibrium. The 22 deep red beads that refer to the binding of 1 with the surface tripeptides were picked out under a microscope. The selected beads were then irradiated with 365 $\mathrm{nm}$ light to remove the photolabile linkers, and the released electrophoric tags were decoded by gas chromatography using an electron capture detector.

Based on this approach, we quickly identified 19 tripeptides having high affinity toward the host molecule 1 (see the Supporting Information). This solid-phase screening showed preference for three peptide sequences: Ac-(D-Ala)-Gly-(D-Ala), Ac-Gly-(D-Ala)-Gly and Ac-(D-Asn)-(L-Ser-(L-Pro). The binding preference for DAla over L-Ala suggests the stereoselective recognition between 1 and peptides derived from alanine residues.

Confirmation of Stereoselective Recognition in Solution System. It is also crucial to evaluate whether the stereoselective recognition in the solid-phase system can also be applied in solution. We thus synthesized four tripeptide isomers, Ac-(D-Ala)-Gly-(D-Ala)- $\mathrm{NHC}_{12} \mathrm{H}_{25}$ (10DD), Ac-(L-Ala)-Gly-(D-Ala)-NHC ${ }_{12} \mathrm{H}_{25}$ (11-LD), Ac-(D-Ala)Gly-(L-Ala)-NHC ${ }_{12} \mathrm{H}_{25}$ (12-DL), and Ac-(L-Ala)-Gly-(L-Ala)$\mathrm{NHC}_{12} \mathrm{H}_{25}(\mathbf{1 3}-\mathrm{LL})$, and examined their binding behaviors with compound $\mathbf{1}$.

The phosphorescence titrations were undertaken to probe the binding of receptor 1 with tripeptides. In this experiment, to a solution of $1\left(4.0 \times 10^{-6} \mathrm{M}\right)$ in $\mathrm{MeOH} /$ $\mathrm{CHCl}_{3}(1: 9,2 \mathrm{~mL})$ at $20{ }^{\circ} \mathrm{C}$ were added aliquots of a specific tripeptide derivative, e.g., 10 -DD (as a $4.0 \times 10^{-3}$ $\mathrm{M}$ solution) in $\mathrm{MeOH} / \mathrm{CHCl}_{3}$ (1:9), and the phosphorescence spectra (with excitation at $466 \mathrm{~nm}$ ) were recorded on individual titration (Figure 4). Despite negligible changes of the absorption spectra, the phosphorescence intensity gradually increases as the concentration of 10DD increases. This indicates the enhancement of phosphorescence yield upon complexation between $\mathbf{1}$ and the tripeptide. Two plausible mechanisms were proposed in an attempt to rationalize the experimental results. Theoretically, via the rigidification effect, ${ }^{24}$ the non- 
TABLE 1. Association Constants and Free Energy Changes for 1/Tripeptide Complexation in $\mathrm{MeOH}^{-\mathrm{CHCl}_{3}}$ (1:9) Solution ${ }^{a}$

\begin{tabular}{cccc}
\hline entry & peptide derivative & $K_{\mathrm{a}}{ }^{b}\left(10^{3} \mathrm{M}^{-1}\right)$ & $\left.\Delta G^{c}(\mathrm{~kJ} \mathrm{~mol})^{-1}\right)$ \\
\hline 1 & Ac-D-Ala-Gly-D-Ala-NHC $\mathrm{NH}_{12} \mathrm{H}_{25}(\mathbf{1 0}-\mathrm{DD})$ & $294 \pm 33$ & -30.7 \\
2 & Ac-L-Ala-Gly-D-Ala-NHC ${ }_{12} \mathrm{H}_{25}(\mathbf{1 1}-\mathrm{LD})$ & $170 \pm 5$ & -29.3 \\
3 & Ac-D-Ala-Gly-L-Ala-NHC $\mathrm{NH}_{12} \mathrm{H}_{25}(\mathbf{1 2}-\mathrm{DL})$ & $154 \pm 27$ & -29.1 \\
4 & Ac-L-Ala-Gly-L-Ala-NHC $\mathrm{H}_{12} \mathrm{H}_{25}(\mathbf{1 3}-\mathrm{LL})$ & $58 \pm 9$ & -26.7
\end{tabular}

${ }^{a}$ Receptor $1\left(4.0 \times 10^{-6} \mathrm{M}\right)$ was titrated with tripeptide $\left(4.0 \times 10^{-3} \mathrm{M}\right)$ in $\mathrm{MeOH} / \mathrm{CHCl}_{3}(1: 9)$ at $293 \mathrm{~K}$.Two or three measurements
were performed for each tripeptide substrate. ${ }^{b}$ The average value derived from the phosphorescence intensity change (as the signal area
between 500 and $850 \mathrm{~nm})$ of two independent titrations. The excitation wavelength $\lambda_{\text {ex }}=466 \mathrm{~nm} .{ }^{c}$ Calculated from $\Delta G=-R T$ ln $K_{\mathrm{a}}$.

radiative decay rates of free receptor $\mathbf{1}$ may be reduced upon multiple hydrogen bonding complexation with tripeptides. This, along with the possible stabilization due to the MLCT in such a supramolecular complex, ${ }^{19}$ may rationalize the phosphorescence enhancement during the titration. Alternatively, the complex formation may, to certain extents, hamper the penetration of the oxygen to proceed with the sensitization. Since the absorption spectral feature both in peak wavelength and absorbance remained unchanged during titration, the latter case seems to be favorable. Though an actual mechanism is pending for resolution, it is unambiguous that the spectral enhancement originates from the multiple hydrogen bonding complexation between 1 and tripeptides. As a result, the corresponding changes of the phosphorescence intensity can be exploited to deduce the thermodynamic parameters upon complexation. The phosphorescence intensity, taken from the signal area between 500 and $850 \mathrm{~nm}$, was then monitored against the concentration of tripeptide. The 1:1 stoichiometry and binding constant $\left(K_{\mathrm{a}}\right)$ of complex (Table 1 ) were determined by curve fitting using the nonlinear least-squares method, taking into account the dilution effect. ${ }^{25}$ The binding strength toward receptor $\mathbf{1}$, according to the deduced association constants (see Table 1), follows an order of 10-DD $>11$-LD $\sim 12$-D; $>13$-LL. This result clearly indicated that receptor $\mathbf{1}$ favorably binds tripeptide 10DD which contains two D-Ala residues. The binding affinity of 10-DD is 5- and 2-fold stronger than its antipode 13-LL and diastereomers 11-LD and 12-DL, respectively. The resulting stereoselectivity in solution is in good agreement with that obtained in the solid-phase library screening.

${ }^{1} \mathrm{H}$ NMR titration experiments provided supportive evidence to the binding modes. When receptor 1 was titrated with tripeptide 10-DD in $\mathrm{CH}_{3} \mathrm{OD} / \mathrm{CDCl}_{3}$ (1:9), the $\mathrm{NH}$ on the tetraamide rings and the $\mathrm{C}_{3} / \mathrm{C}_{3^{\prime}}$ protons on the bipyridinediamide rings (see structure $\mathbf{1}$ in Figure 2 for numbering) showed significant changes in chemical shifts (Figure 5). This result indicated that the bipyridinediamide moiety, in addition to the $\mathrm{A}_{2} \mathrm{~B}_{2}$ motifs, also contributed considerable hydrogen bondings to the complexation with the tripeptide substrate. The NMR analysis indicated that compound $\mathbf{1}$ might exist as a mixture of two diastereomers $(\sim 1: 1)$ with different configurations $(\Delta$ or $\Lambda$ ) at the ruthenium center. Upon addition of more than 22 equiv of $10-\mathrm{DD}$, the $\mathrm{C}_{3} / \mathrm{C}_{3^{\prime}}$ protons (at $\sim 9.35 \mathrm{ppm}$ ) shifted downfield and split into two signals, which might account for the two diastereomeric complexes of 1/10-DD.

(24) (a) Sandanayaka, K. R. A. S.; Nakashima, K.; Shinkai, S. Chem. Commun. 1994, 1621. (b) Fang, J.-M.; Selvi, S.; Liao, J.-H.; Slanina, Z.; Chen, C.-T.; Chou, P.-T. J. Am. Chem. Soc. 2004, 126, 3559-3566.

(25) Connors, K. A. Binding Constants; Wiley: New York, 1987.
A similar phenomenon was also observed in the titration spectra of 1 with 13-LL (see the Supporting Information). Due to the complex proton configuration, further calculation of the binding constants on the basis of the concentration dependent chemical-shifts is impractical. Note that in the phosphorescence titration, to simplify the derivation, the emission yields of two diastereomeric complexes of 1/10-DD are assumed to be the same.

In comparison, a prototype $\mathrm{A}_{2} \mathrm{~B}_{2}$ molecule 14 was prepared and subjected to ${ }^{1} \mathrm{H}$ NMR titration with alanine derivatives in $\mathrm{CDCl}_{3}$ solution. The results revealed that molecule 14 exhibited a weak binding with 3,5-dinitrobenzoylalanine hexylamide (15) albeit no apparent binding with Ac-Ala-OMe ester. The association constants for both 14/15-D and 14/15-L complexes at $295 \mathrm{~K}$ in $\mathrm{CDCl}_{3}$ were estimated to be in a range of $50-150 \mathrm{M}^{-1}$, which are 3 orders of magnitude weaker than that of 1/10-DD. Unfortunately, a similar titration experiment for 14 using 10-DD was not feasible due to the sparse solubility of tripeptide in $\mathrm{CDCl}_{3}$, neither could the titration experiments be conducted in protic solvents, e.g., $\mathrm{CD}_{3} \mathrm{OD} / \mathrm{CDCl}_{3}$ (1:9), due to the complicated exchange of amido protons.
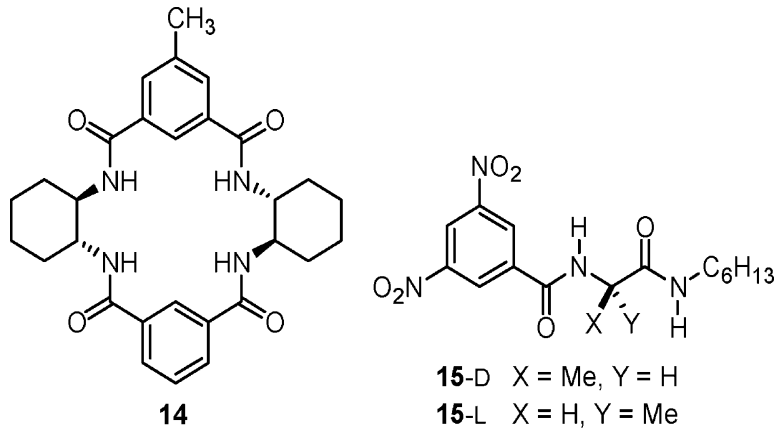

We also prepared the analogues of 10-DD and 11-LD by replacing the acetyl (Ac) capping group with a bulky tertbutyloxycarbonyl ( $t$-Boc) group. These $t$-Boc analogues turned out to have very weak affinity toward molecule $\mathbf{1}$, and no apparent change of the phosphorescence was observed. Since the bipyridinediamide moiety in molecule $\mathbf{1}$ also participated in the molecular recognition of tripeptides 10-DD and 11-LD (vide supra), introducing a bulky $t$-Boc group might not fit in the interior binding pocket of $\mathbf{1}$.

Conclusion. We have demonstrated the differentiation of four tripeptide isomers of Ac-Ala-Gly-Ala- $\mathrm{NHC}_{12} \mathrm{H}_{25}$ via a deliberately designed chiral receptor. The twoarmed receptor $\mathbf{1}$ incorporating a bipyridinediamide moiety and two chiral cylcotetraamide motifs achieves an effective multiple hydrogen bondings recognition with tripeptides in a stereoselective manner. The attachment 

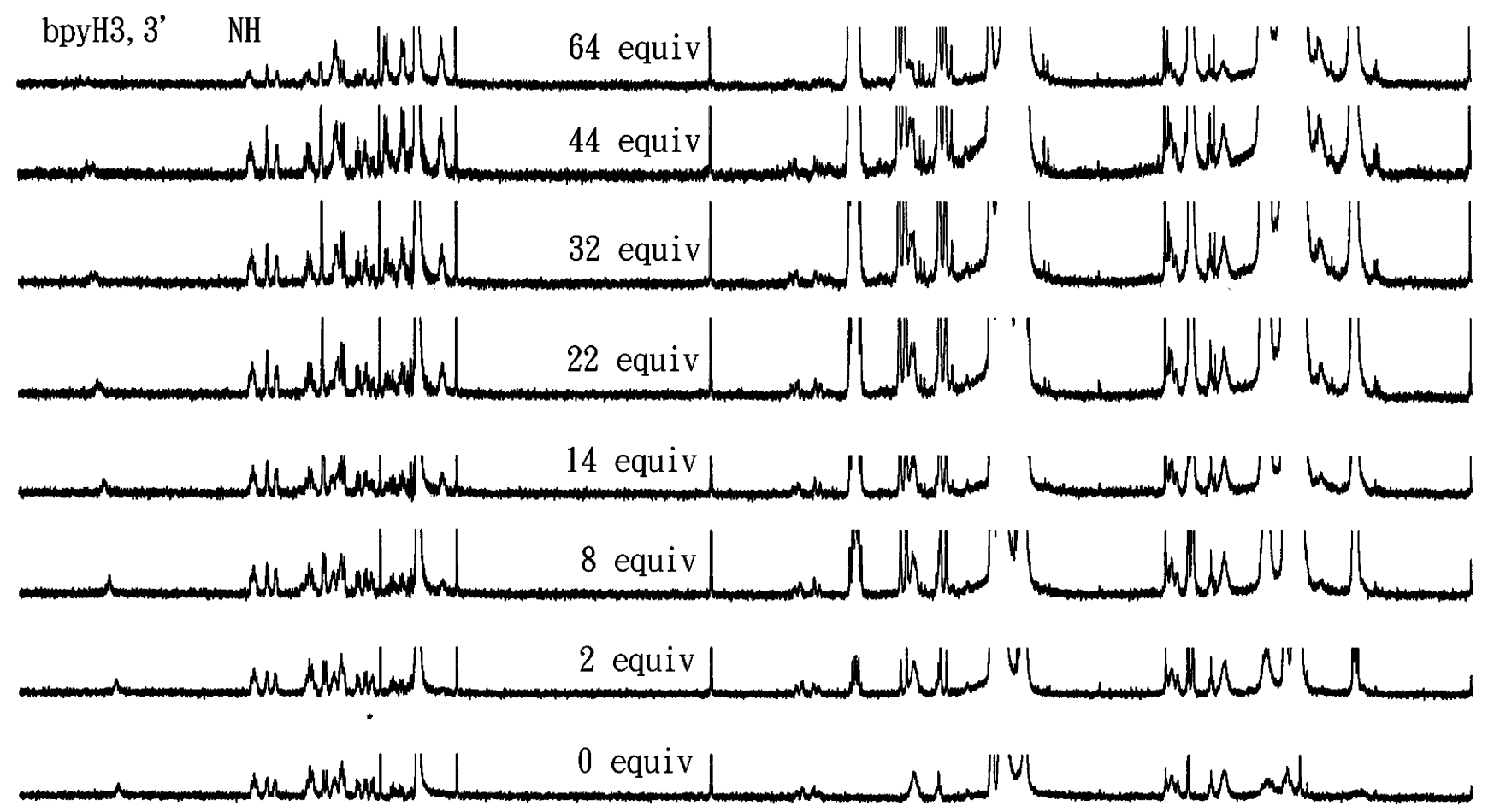

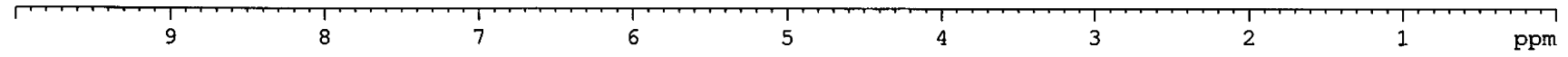

FIGURE 5. ${ }^{1} \mathrm{H}$ NMR titration of compound $\mathbf{1}\left(1 \times 10^{-4} \mathrm{M}\right)$ by addition of various amounts of 10-DD [as $1 \times 10^{-2} \mathrm{M}$ solution in $\left.\mathrm{CH}_{3} \mathrm{OD} / \mathrm{CDCl}_{3}(1: 9)\right]$.

of a $\mathrm{Ru}(\mathrm{II})$ reporter renders a real-time detection of the binding property based on the phosphorescence spectroscopy. This, in combination with the encoded library screening ${ }^{21}$ technique, proves to be a rapid and efficient method for search and sensing of target peptides.

\section{Experimental Section}

Synthesis of Cyclotetraamide 9. To a solution of 5-azidomethylisophthalic acid (301 mg, $1.36 \mathrm{mmol})$ in $\mathrm{CH}_{2} \mathrm{Cl}_{2}(35$ $\mathrm{mL}$ ) was added a solution of pentafluorophenol (563 mg, 3.06 $\mathrm{mmol})$ and $\mathrm{EDC}(586 \mathrm{mg}, 3.06 \mathrm{mmol})$ in $\mathrm{CH}_{2} \mathrm{Cl}_{2}(10 \mathrm{~mL})$. The mixture was stirred for $3 \mathrm{~h}$ at room temperature, concentrated, and purified by flash chromatography on a silica gel column (EtOAc/hexane, 1:9) to afford 5-azidomethylisophthalic acid dipentafluorophenyl ester as white solids (741 mg, 98\%).

Diamide $8^{16 \mathrm{~b}}(1.75 \mathrm{~g}, 3.1 \mathrm{mmol})$ in $\mathrm{CH}_{2} \mathrm{Cl}_{2}(56 \mathrm{~mL})$ was treated with TFA $(14 \mathrm{~mL})$ for $1.5 \mathrm{~h}$ at room temperature to remove the Boc protecting groups. The reaction mixture was concentrated under reduced pressure and triturated several times with $\mathrm{Et}_{2} \mathrm{O}$ to give precipitates. The solids were collected and dried in vacuo for at least $6 \mathrm{~h}$ to afford the corresponding TFA salt (1.83 g, quantitative yield).

To a mixture of 5-azidomethyl-isophthalic acid dipentafluorophenyl ester $(1.53 \mathrm{~g}, 2.77 \mathrm{mmol})$ and the above prepared TFA salt $(1.60 \mathrm{~g}, 2.77 \mathrm{mmol})$ suspended in $\mathrm{CH}_{2} \mathrm{Cl}_{2}(65 \mathrm{~mL})$ was added $i$-Pr $\mathrm{Pr}_{2} \mathrm{NEt}$ (2.85 g. $22 \mathrm{mmol}$ ) dropwise over a period of $10 \mathrm{~min}$ at room temperature. The mixture was stirred for 12 h, concentrated, and purified by chromatography on a silica gel column $\left(\mathrm{CH}_{3} \mathrm{OH} / \mathrm{CH}_{2} \mathrm{Cl}_{2}, 1: 19\right)$ to afford compound 9 as white solids $(1.49 \mathrm{~g}, 99 \%): \mathrm{mp}>320{ }^{\circ} \mathrm{C}$; TLC $\left(\mathrm{MeOH} / \mathrm{CHCl}_{3}\right.$ (1:19)) $R_{f}=0.2 ; \mathrm{IR}$ (KBr) 3315, 3072, 2105, $1657 \mathrm{~cm}^{-1} ;{ }^{1} \mathrm{H}$ NMR (DMSO- $\left.d_{6}, 400 \mathrm{MHz}\right) \delta 8.41(2 \mathrm{H}, \mathrm{d}, J=7.6 \mathrm{~Hz}), 8.36(2 \mathrm{H}, \mathrm{d}$, $J=7.6 \mathrm{~Hz}), 8.23(1 \mathrm{H}, \mathrm{s}), 8.21(1 \mathrm{H}, \mathrm{s}), 7.80(2 \mathrm{H}, \mathrm{dd}, J=7.6$, $1.6 \mathrm{~Hz}), 7.78(2 \mathrm{H}, \mathrm{s}), 4.55(2 \mathrm{H}, \mathrm{s}), 3.89(4 \mathrm{H}, \mathrm{m}), 1.96-1.93(4$ $\mathrm{H}, \mathrm{m}), 1.77-1.74(4 \mathrm{H}, \mathrm{m}), 1.60-1.50(4 \mathrm{H}, \mathrm{m}), 1.35-1.25$ (4
$\mathrm{H}, \mathrm{m}) ;{ }^{13} \mathrm{C}$ NMR (DMSO- $\left.d_{6}, 100 \mathrm{MHz}\right) \delta 166.7$ (C), $166.3(\mathrm{C})$, $136.4(\mathrm{C}), 135.4(\mathrm{C}), 134.9(\mathrm{C}), 129.7(\mathrm{CH}), 129.4(\mathrm{CH}), 128.3$ $(\mathrm{CH}), 126.7(\mathrm{CH}), 126.5(\mathrm{CH}), 53.8(\mathrm{CH}), 53.7(\mathrm{CH}), 53.0\left(\mathrm{CH}_{2}\right)$, $31.5\left(\mathrm{CH}_{2}\right), 24.7\left(\mathrm{CH}_{2}\right)$; FAB-MS $\mathrm{m} / z$ (rel intensity) $544(\mathrm{M}+$ $\left.\mathrm{H}^{+}, 30\right)$; HRMS calcd for $\mathrm{C}_{29} \mathrm{H}_{34} \mathrm{~N}_{7} \mathrm{O}_{4}\left(\mathrm{M}+\mathrm{H}^{+}\right)$544.2672, found 544.2665 .

Synthesis of Molecular Sensor 1. To a solution of azide 9 (500 mg, $0.92 \mathrm{mmol})$ in THF (40 mL) was added solid $\mathrm{PPh}_{3}$ (362 mg, $1.38 \mathrm{mmol}$ ) at room temperature. The mixture was refluxed for $2 \mathrm{~h}$ until no nitrogen evolved. The solution was cooled, and a mixture of $\mathrm{H}_{2} \mathrm{O}(0.2 \mathrm{~mL})$ and $\mathrm{THF}(9 \mathrm{~mL})$ was added. The mixture was refluxed for an additional $14 \mathrm{~h}$, concentrated, and purified by chromatography on a silica gel column $\left(\mathrm{CH}_{3} \mathrm{OH} / \mathrm{CHCl}_{3}, 1: 4\right)$ to give the corresponding amine as white solids (433 $\mathrm{mg}, 87 \%)$.

The amine product (350 mg, $0.68 \mathrm{mmol}$ ) was added to a suspension of 2,2'-bipyridyl-4,4'-dicarboxylic acid ( $83 \mathrm{mg}, 0.34$ $\mathrm{mmol})$ and HOBt $(94 \mathrm{mg}, 0.70 \mathrm{mmol})$ in DMF $(10 \mathrm{~mL})$ at $0{ }^{\circ} \mathrm{C}$, followed by addition of EDC (142 $\mathrm{mg}, 0.74 \mathrm{mmol})$. The mixture was stirred for $1 \mathrm{~h}$ at $0{ }^{\circ} \mathrm{C}$ and $49 \mathrm{~h}$ at room temperature to give a pink suspension. The reaction mixture was concentrated under reduced pressure, dissolved in $\mathrm{CH}_{3} \mathrm{OH} / \mathrm{CHCl}_{3}$ (1:9), and washed twice with $\mathrm{H}_{2} \mathrm{O}$. The aqueous phase was extracted three times with $\mathrm{CH}_{3} \mathrm{OH} / \mathrm{CHCl}_{3}$ (1:9). The combined organic phase was dried over anhydrous $\mathrm{Na}_{2} \mathrm{SO}_{4}$ and filtered, and the filtrate was concentrated to give pale pink solids. The crude product was purified by chromatography on a silica gel column $\left(\mathrm{CH}_{3} \mathrm{OH} / \mathrm{CHCl}_{3}, 1: 9\right)$ to afford the two-arm bipyridyl ligand as white solids ( $367 \mathrm{mg}, 87 \%$ ).

A mixture of the two-arm bipyridyl ligand $(59 \mathrm{mg}, 0.047$ $\mathrm{mmol})$ and cis- $\mathrm{Ru}(\mathrm{bpy})_{2} \mathrm{Cl}_{2}$ hydrate $(25 \mathrm{mg}, 0.052 \mathrm{mmol})$ in EtOH $(8 \mathrm{~mL})$ and $\mathrm{H}_{2} \mathrm{O}(2 \mathrm{~mL})$ was heated under reflux for 6 h. After removal of solvents, the residue was dissolved in $\mathrm{CH}_{2}$ $\mathrm{Cl}_{2}$ and triturated with $\mathrm{Et}_{2} \mathrm{O}$. The solids were collected by filtration, washed with $\mathrm{CH}_{2} \mathrm{Cl}_{2} / \mathrm{Et}_{2} \mathrm{O}$ (1:3), and dried in vacuo to afford the chloride salt of $\mathbf{1}(75 \mathrm{mg})$. The chloride salt was 
dissolved in $\mathrm{H}_{2} \mathrm{O}$, and treated with saturated $\mathrm{NH}_{4} \mathrm{PF}_{6}$ aqueous solution $(5 \mathrm{~mL})$. The mixture was stirred for $30 \mathrm{~min}$ at room temperature, filtered, and washed with cold water to give the phosphorus hexafluoride salt of $\mathrm{Ru}(\mathrm{II})$ sensor $\mathbf{1}$ as orange red solids: $\mathrm{mp}>330{ }^{\circ} \mathrm{C}$ dec; yield $77 \mathrm{mg}$ (83\%); IR (KBr) 3422, $2942,1654,1540 \mathrm{~cm}^{-1}$; ${ }^{1} \mathrm{H}$ NMR (DMSO- $\left.d_{6}, 500 \mathrm{MHz}\right) \delta 9.72$ $(2 \mathrm{H}, \mathrm{s}), 9.24(2 \mathrm{H}, \mathrm{s}), 8.83(6 \mathrm{H}, \mathrm{m}), 8.37(4 \mathrm{H}, \mathrm{m}), 8.22-8.13(8 \mathrm{H}$, m), 7.90-7.67 (16H, m), 7.52-7.45 (8H, m), $4.45(4 \mathrm{H}, \mathrm{m}), 3.88$ $(8 \mathrm{H}, \mathrm{m}), 1.96-1.90(8 \mathrm{H}, \mathrm{d}), 1.92(8 \mathrm{H}, \mathrm{m}), 1.74(8 \mathrm{H}, \mathrm{m}), 1.52$ $(8 \mathrm{H}, \mathrm{m}), 1.31(8 \mathrm{H}, \mathrm{m}) ;{ }^{13} \mathrm{C}$ NMR (DMSO- $\left.d_{6}, 125 \mathrm{MHz}\right) \delta 166.6$ (C), 166.5 (C), 166.4 (C), $162.9(\mathrm{C}), 157.1(2 \times \mathrm{C}), 152.0(\mathrm{CH})$, $151.6(\mathrm{CH}), 151.3(\mathrm{CH}), 141.4(\mathrm{C}), 139.0(\mathrm{CH}), 138.2(\mathrm{CH})$, $135.1(\mathrm{C}), 134.9(\mathrm{C}), 129.6(\mathrm{CH}), 129.0(\mathrm{CH}), 128.3(\mathrm{CH}), 127.9$ $(\mathrm{CH}), 126.7(\mathrm{CH}), 125.7(\mathrm{CH}), 125.4(\mathrm{CH}), 124.5(\mathrm{CH}), 122.0$ $(\mathrm{CH}), 53.5(\mathrm{CH}), 42.8\left(\mathrm{CH}_{2}\right), 31.5\left(\mathrm{CH}_{2}\right), 24.7\left(\mathrm{CH}_{2}\right)$; FAB-MS $m / z$ (rel intensity) $1802\left(\mathrm{M}+\mathrm{H}^{+}-\mathrm{PF}_{6}\right), 1658\left(\mathrm{M}+\mathrm{H}^{+}-2\right.$ $\mathrm{PF}_{6}$ ).

Phosphorescence Titration Studies. Phosphorescence spectra were recorded on AMINCO/Bowman Series 2 spectrometer. A solution of compound $1\left(4.0 \times 10^{-6} \mathrm{M}\right)$ in $\mathrm{MeOH} /$ $\mathrm{CHCl}_{3}(1: 9,2 \mathrm{~mL})$ was placed in a quartz cuvette $(1 \mathrm{~cm}$ width $)$ at $293 \mathrm{~K}$. Aliquots of tripeptide derivative $\left(4.0 \times 10^{-3} \mathrm{M}\right)$ in $\mathrm{MeOH} / \mathrm{CHCl}_{3}$ (1:9) were added in an incremental fashion $(0.5$, $1,2,3,4,6,10,15,30,40$, and 60 equiv). The phosphorescence spectra with $466-\mathrm{nm}$ excitation were recorded for each addition. The phosphorescence intensity (as the signal area between 500 and $850 \mathrm{~nm}$ ) was monitored as a function of tripeptide concentrations. Nanosecond-microsecond lifetime studies were performed by an Edinburgh FL 900 photoncounting system with a hydrogen-filled/or a nitrogen lamp as the excitation source. The emission decays were analyzed by the sum of exponential functions, which allows partial removal of the instrument time broadening and consequently renders a temporal resolution of $\sim 200 \mathrm{ps}$.
The binding constant of complex and 1:1 stoichiometry were determined by curve fitting using the nonlinear least-squares method, and the association constant $\left(K_{\mathrm{a}}\right)$ is derived from the following equation. ${ }^{22}$

$$
\begin{aligned}
F=F_{0}+\left(\Delta F_{\max } / 2 C_{0}\right)\left\{1 / K_{\mathrm{a}}+\right. & C_{0}+C- \\
& {\left.\left[\left(1 / K_{\mathrm{a}}+C_{0}+C\right)^{2}-4 C_{0} C\right]^{1 / 2}\right\} }
\end{aligned}
$$

$F$ is the emission intensity, $F_{0}$ is the original emission intensity of the free receptor, and $\Delta F_{\max }$ is the largest change of emission intensity after saturation with the substrate. $C$ is the concentration of substrate; $C_{0}$ is the initial concentration of the receptor.

${ }^{1} \mathbf{H}$ NMR Titration Studies. ${ }^{1} \mathrm{H}$ NMR spectra were measured on a Bruker Avance-400 NMR spectrometer. A typical experiment was performed as follows. A solution of compound $1\left(1.0 \times 10^{-4} \mathrm{M}\right)$ in $\mathrm{CD}_{3} \mathrm{OD} / \mathrm{CDCl}_{3}(1: 9,0.5 \mathrm{~mL})$ was placed in a 5-mm NMR tube. A small aliquot of tripeptide derivative $\left(1.0 \times 10^{-2} \mathrm{M}\right.$, e.g., Ac-D-Ala-Gly-D-Ala- $\left.\mathrm{NHC}_{12} \mathrm{H}_{25}\right)$ in $\mathrm{CD}_{3} \mathrm{OD} /$ $\mathrm{CDCl}_{3}(1: 9)$ was added in an incremental fashion $(2,8,14,22$, 32,44 , and 64 equiv), and their corresponding spectra were recorded. The chemical-shift changes of $\mathrm{NH}$ on the tetraamide rings and $\mathrm{C}_{3} / \mathrm{C}_{3^{\prime}}-\mathrm{H}$ were monitored as a function of tripeptide concentrations.

Acknowledgment. We thank the National Science Council for financial support.

Supporting Information Available: Synthetic procedures, table of 19 tripeptides selected by encoded screening, and absorption, phosphorescence, and NMR spectra. This material is available free of charge via the Internet at http://pubs.acs.org.

JO048368S 